\title{
Mycorrhizal symbiosis changes host nitrogen source use
}

\author{
Tiina Savolainen • Minna-Maarit Kytöviita
}

Received: 16 June 2021 / Accepted: 2 December 2021 / Published online: 9 December 2021

(C) The Author(s) 2021

\begin{abstract}
Purpose The ecological importance of arbuscular mycorrhizal fungi (AMF) in plant acquisition of inorganic and organic sources of nitrogen $(\mathrm{N})$ is not clear. To improve understanding of the plant $\mathrm{N}$ nutrition ecology, we tested the effect of intraspecific competition and AMF in plant $\mathrm{N}$ source use in growth and $\mathrm{N}$ acquisition.

Methods Solidago virgaurea was grown in microcosms in a fully factorial experiment under greenhouse conditions. The factors tested were intraspecific competition between seedlings and adult plants (yes, no), $\mathrm{N}$ source $\left(\mathrm{NH}_{4}\right.$, glycine) and AMF (inoculated with Glomus hoi, not inoculated).

Results When grown separately, non-mycorrhizal seedling growth was highest when grown with ammonium, but non-mycorrhizal adults grew best with glycine as the sole N source. Mycorrhizal symbiosis with Glomus hoi evened out this initial niche partitioning in terms of differences in $\mathrm{N}$ source use
\end{abstract}

Responsible Editor: Jan Jansa.

Supplementary Information The online version contains supplementary material available at https://doi. org/10.1007/s11104-021-05257-5.

T. Savolainen · M.-M. Kytöviita $(\bowtie)$

Department of Biological and Environmental

Science, University of Jyvaskyla, P.O. Box 35,

FIN-40014 Jyvaskyla, Finland

e-mail: minna-maarit.kytoviita@jyu.fi and all mycorrhizal plants grew best with ammonium. Competition shaped plant benefit from mycorrhizal symbiosis depending on the $\mathrm{N}$ source. Competition reduced mycorrhizal growth benefit in glycine-grown seedlings, but not in adults. Plant performance did not show uniform relationship with $\delta^{15} \mathrm{~N}$, but $\delta^{15} \mathrm{~N}$ was affected by life stage, competition and mycorrhiza.

Conclusions Plant competition and AMF shape plant $\mathrm{N}$ source use. Plant and AMF benefit of the symbiosis depend on the $\mathrm{N}$ source.

Keywords Arbuscular mycorrhizal fungi (AMF) . niche partitioning $\cdot$ nitrogen $(\mathrm{N}) \cdot \delta^{15} \mathrm{~N}$ isotopic signatures $\cdot$ Solidago virgaurea plant competition . Arctic
Abbreviations
AMF Arbuscular mycorrhizal fungi
NM Non-mycorrhizal
$\mathrm{N}$ nitrogen

\section{Introduction}

In plant communities, access to multiple nitrogen $(\mathrm{N})$ sources may enhance plant performance and alter ecological interactions in ways that may promote coexistence. Plants capture $\mathrm{N}$ in a variety of different chemical forms ranging from inorganic sources such as nitrate and ammonium to amino acids (Lipson and Näsholm 2001; Schimel and Bennett 2004). Plants 
may prefer a particular inorganic or organic $\mathrm{N}$ source. Preference for a given $\mathrm{N}$ source may manifest itself as increased uptake and/or enhanced growth (Britto and Kronzucker 2013). The N source preferences of a plant are likely related to the most abundant $\mathrm{N}$ sources in the soil where the species grows, but it can also be related to the energy required for uptake, assimilation and storage, and to plant physiological status (Britto and Kronzucker 2013).

Terrestrial plants take up inorganic $\mathrm{N}$ from the soil mainly as ammonium and nitrate (Stitt et al. 2002). However, the soil $\mathrm{N}$ in the Arctic, alpine tundra and boreal forests can be predominantly in organic form (Kielland 1994, 1995; Lipson et al. 1999; Näsholm et al. 1998; Stark and Kytöviita 2006). In these strongly $\mathrm{N}$ limited ecosystems, plants can take up dissolved organic $\mathrm{N}$ directly from the soil in the form of amino acids, thereby circumventing part of the $\mathrm{N}$ mineralization process (Chapin et al. 1993; Kielland 1994; Nordin et al. 2004). Another feature of cold climate boreal ecosystems is that grazing by large ungulates strongly influences plant community structure (Olofsson et al. 2001). Large herbivore urine provides resources that are rich in labile nutrients, such as ammonium, and can stimulate soil microbial processes and $\mathrm{N}$ mineralization rates in nutrient poor tundra (Stark et al. 2002). In addition, the presence of mycorrhizal symbioses in most plant species improves access to both inorganic and organic sources of N (Hodge and Storer 2014). Although mycorrhizal symbiosis has an essential role in plant nutrition and ecosystem dynamics, exactly how mycorrhizas affect plant $\mathrm{N}$ acquisition, use and competition for $\mathrm{N}$ is not fully understood.

Mycorrhizal fungi form symbiotic associations with plant roots, transferring soil nutrients to the plant in exchange for carbon (Smith and Read 2008). This mutualistic relationship is hypothesized to have played a major role in the colonization of land by plants and the majority of plant families are mycorrhizal (Brundrett 2002; Redecker et al. 2000). In the low Arctic, plants are usually colonized by arbuscular mycorrhizal fungi (AMF) (Gardes and Dahlberg 1996; Kytöviita et al. 2011; Pietikäinen et al. 2005) which have traditionally been associated with enhanced plant phosphorus nutrition. However, it has been shown that AMF may also enhance plant nitrogen acquisition and are capable of taking up inorganic $\mathrm{N}\left(\mathrm{NO}_{3}-\right.$ or $\left.\mathrm{NH}_{4}+\right)$ (Govindarajulu et al. 2005) and organic N (amino acids) (Näsholm et al. 1998; Whiteside et al. 2012) and transfer the $\mathrm{N}$ to the host plant. While these studies make an important contribution to our understanding of the role of AMF in plant $\mathrm{N}$ nutrition, there is need for information about the ecological relevance of the mycorrhizal pathway in plant $\mathrm{N}$ acquisition.

Competition between plants is an important factor structuring plant communities (Keddy 2001; Grace and Tilman 2003). Especially in habitats where nutrient availability is strongly limiting plant growth, such as in Arctic tundra, belowground competition for soil resources is critical in community assembly. Mycorrhizal association directly increases the potential acquisition of soil nutrients (Smith and Read 2008) and, as a result, it may directly influence plant-plant competition (Mickan et al. 2021). AMF mycelium may simultaneously colonize several individuals within a plant community linking plants into a common mycelial network (van der Heijden and Horton 2009). The benefit to a network member may differ from that when isolated, but no general rule has emerged as to how the benefit is distributed in AMF networks. AMF has been shown to mediate facilitation between adult plants and seedlings by promoting seedling establishment and nutrition (van der Heijden 2004). However, other studies have demonstrated negative effects of AMF on seedling growth in presence of adults (e.g. Moora and Zobel 1998; Pietikäinen and Kytöviita 2007).

The abundance of ${ }^{15} \mathrm{~N}$ is a useful indicator of the sources and pathways of nitrogen flow in ecosystem studies (Högberg 1997). The natural abundance method measures the ratio of the less common heavy ${ }^{15} \mathrm{~N}$ and the predominant lighter ${ }^{14} \mathrm{~N}$ isotopes and provides the $\delta^{15} \mathrm{~N}$ signal of a sample. Most physi$\mathrm{cal}$, chemical and biochemical processes in nature favor the lighter isotope, leaving the sample enriched with the heavy isotope (Hobbie and Högberg 2012). The $\delta^{15} \mathrm{~N}$ in plants is an indicator of plant $\mathrm{N}$ source because different $\mathrm{N}$ sources have different isotopic signals (Dawson et al. 2002). Plant $\delta^{15} \mathrm{~N}$ reflects the net outcome of plant $\mathrm{N}$ acquisition processes (Evans 2001; Robinson 2001) and therefore can be used as an integrator of $\mathrm{N}$ dynamics. AMF symbiosis may alter plant $\mathrm{N}$ isotopic signatures, although conflicting evidence is reported for different species and experimental settings. For example, an increase (Azcon et al. 1998; Fonseca et al. 2001) or decrease (Azcon et al. 
1998; Handley et al. 1993) in plant shoot $\delta^{15} \mathrm{~N}$ values have been reported in Glomus spp. inoculated plants in comparison to non-inoculated controls. Such differences may be attributed to different plant species or $\mathrm{N}$ sources with varying $\delta^{15} \mathrm{~N}$ signatures. However, clear support for these explanations is lacking and the reasons for $\delta^{15} \mathrm{~N}$ differences between arbuscular mycorrhizal versus nonmycorrhizal plants remain elusive.

Niche divergence through differences in $\mathrm{N}$ use and microbial associations may be a mechanism of coexistence and influence population and community processes (McKane et al. 2002). In this work, we investigated the role of AMF in plant competition. We used the low Arctic herb Solidago virgaurea as a model species in greenhouse experiments where plants were grown with AMF or in non-mycorrhizal conditions. In the experiments, we explored the role of AMF and plant life stage (adult, seedling) on plant $\mathrm{N}$ source use. The acquisition and use of given source of $\mathrm{N}$ was determined by biomass, $\mathrm{N}$ gain and $\delta^{15} \mathrm{~N}$ of the plants. Specifically, we ask how AMF symbiosis and competition affect the use of inorganic $\mathrm{N}$ and organic $\mathrm{N}$ in two plant life stages. The role of AMF symbiosis in plant $\mathrm{N}$ economy was further evaluated by calculating mycorrhizal benefit in the plant life stages when grown with inorganic and organic $\mathrm{N}$.

\section{Methods}

\section{Study organisms}

Solidago virgaurea $\mathrm{L}$. is an herbaceous perennial plant of the family Asteraceae and it is a very common species in low Arctic habitats (Hultén and Fries 1986). It is one of the preferred forage species by reindeer (Skogland 1980). In the field S. virgaurea has high and stable arbuscular mycorrhizal colonization levels (Kytöviita et al. 2011) which may reach over $90 \%$ of root length colonized. The plant forms a rosette of leaves and one or several floral shoots of 15 to $30 \mathrm{~cm}$ in height in the Arctic. The leaves wither in the end of the growing season. Solidago virgaurea spreads mainly by wind-dispersed seeds (Jalas 1980) of which the majority fall and germinate in the vicinity of the mother plant. Solidago virgaurea seeds for the present experiment were collected from Kilpisjärvi $\left(69^{\circ} 03^{\prime} \mathrm{N}, 20^{\circ} 50^{\prime} \mathrm{E}\right)$ and stored dry at $+4^{\circ} \mathrm{C}$ until used in the experiment.
Glomus hoi, the AMF used in this study system originated from the same low Arctic meadow as the seed material and is accessible in the Bank of European Glomales under the isolate number BEG 104. The G. hoi isolate was maintained with Plantago lanceolata L. as a host for the present experiment. The host plants were grown in pots filled with sterilized substrate (autoclaved mixture of soil, sand and perlite). The AMF spores were washed from the substrate and collected on a $50 \mu \mathrm{m}$ sieve. Each experimental plant assigned to mycorrhizal treatment received approximately 300 spores in $45 \mathrm{ml}$ water. The nonmycorrhizal (NM) inoculum was prepared similarly, but by allowing the water used in washing the AMF spores from the substrate sediment for 30 minutes and filtering the water through a filter paper $(10 \mu \mathrm{m}$ pore size). We checked the final product under microscope and verified the lack of AMF spores or hyphae. NM plants received $45 \mathrm{ml}$ of the NM inoculum.

\section{Experimental design}

We compared seedling and adult plant responses to one inorganic and one organic $\mathrm{N}$ source, AMF and competition in a fully factorial greenhouse experiment. There were either three seedlings or one adult in the non-competition pots. In the competition treatment, three seedlings were grown together with an adult plant. Half of the pots were inoculated with AMF (60 pots) and half remained non-mycorrhizal (60 pots). Half of the pots (60 pots) received glycine and the other half (60 pots) $\mathrm{NH}_{4}$ as the $\mathrm{N}$ source. Ten pots were allocated to each treatment combination; therefore, the total number of pots was 120 and the total number of adult plants 80 and the number of three seedling units 80 . The number of plants exceeds the number of pots as the adults and seedlings were grown in the same pots in the competition treatment. We selected ammonium as the inorganic $\mathrm{N}$ in this experiment, because, in contrast to temperate forests or agricultural soils, nitrate concentrations in tundra soils are often minor (Nordin et al. 2004; Stark 2007). Glycine was selected as the organic source of $\mathrm{N}$ because it is reported to be the most abundant amino acid in Arctic soils (Kielland 1994) and because plants appear to utilize glycine better than more complex amino acids (Kielland 1994; Lipson et al. 1999). The use of both selected $\mathrm{N}$ sources by 
Solidago virgaurea was verified in a screening experiment (Appendix 1).

To prepare the adult plant material for the experiment, Solidago virgaurea plants were pre-grown in autoclaved and washed sand-perlite mixture for 142 days. During that time the plants were given halfstrength Ingestad solution (Ingestad 1960) once a week. We stopped giving fertilizer to the adult plants 14 days before the experiment began. After pre-growing, the adult plants and two-week-old Solidago virgaurea seedlings raised in washed autoclaved sand were washed and transferred to experimental pots (6 $\mathrm{cm} \varnothing)$ and their roots were embedded into autoclaved sand-perlite (9:1) mixture. Average dry weight of the adult plants at the beginning of the experiment was $315.1 \pm 99.6 \mathrm{mg}$ and that of the seedlings was $1.8 \pm$ $0.2 \mathrm{mg}$.

Seedlings in the competition pots were planted in such a way that the adult plant did not markedly shade the seedlings. In the AMF treatment, plants were inoculated with $G$. hoi spores (300 spores per pot) by applying the spores evenly to the top $5 \mathrm{~cm}$ of the growth substrate. NM treatments received same amount of $\mathrm{NM}$ inoculum the same way. Ammonium $\left(\left(\mathrm{NH}_{4}\right)_{2} \mathrm{SO}_{4}\right)$ or glycine $\left(\mathrm{C}_{2} \mathrm{H}_{5} \mathrm{NO}_{2}\right)$ was administered as $51.2 \mu \mathrm{M} \mathrm{N}$ solution by pouring evenly 100 $\mathrm{ml}$ once a week to each tray containing 10 pots. Other nutrients were provided to plants in modified Hoagland's solution (Hoagland and Arnon 1965). The N-free Hoagland's solution contained: $1.2 \mu \mathrm{M}$ $\mathrm{K}_{2} \mathrm{CO}_{3}, 0.4 \mu \mathrm{M} \quad \mathrm{KH}_{2} \mathrm{PO}_{4}, 0.2 \mu \mathrm{M} \mathrm{MgSO}_{4} \times 7 \mathrm{H}_{2} \mathrm{O}$, $0.8 \mu \mathrm{M} \mathrm{CaCl}_{2} \times 2 \mathrm{H}_{2} \mathrm{O}, 0.8 \mathrm{nM} \mathrm{ZnSO} \mathrm{Zn}_{4} \times \mathrm{H}_{2} \mathrm{O}, 0.8 \mathrm{nM}$ $\mathrm{MnCl}_{2} \times 4 \mathrm{H}_{2} \mathrm{O}, 0.2 \mathrm{nM} \mathrm{CuSO} \mathrm{x}_{4} \times \mathrm{H}_{2} \mathrm{O}, 10 \mathrm{nM} \mathrm{H} \mathrm{BO}_{3}$, $0.2 \mathrm{nM} \mathrm{MoNa}_{2} \mathrm{O}_{4} \times 2 \mathrm{H}_{2} \mathrm{O}, 0.8 \mathrm{nM} \mathrm{NaCl}$ and $9 \mathrm{nM}$ $\mathrm{FeSO}_{4} \times 7 \mathrm{H}_{2} \mathrm{O}$. The Hoagland's nutrient solution was applied on trays containing 10 pots at the rate of 100 $\mathrm{ml}$ per week. In addition, distilled water was given to keep all the pots well-watered. Conditions in the greenhouse were set for $22^{\circ} \mathrm{C}$ temperature, $18 \mathrm{~h}$ light and $60 \%$ relative air humidity.

The experiment lasted 15 weeks. At the end, the plants were weighed and dried at $65^{\circ} \mathrm{C}$ for $24 \mathrm{~h}$. Before drying the roots, a sample was taken from fresh root material to measure AMF colonization. This root loss was accounted for when calculating the root dry weight. Fresh root samples were stored in 50\% ethanol. Root samples were stained with $0.2 \%$ trypan blue and scored according to the method by McGonigle et al. (1990) to evaluate the colonization frequency of roots by the mycorrhizal fungus. We did not detect any mycorrhizal fungal structures in the roots in the plants in the non-mycorrhizal treatment and only AMF inoculated colonization levels are reported.

\section{Stable isotopic signatures}

Foliage in half of the plants was analysed for $\mathrm{N}$ contents by randomly allocating five out of the 10 plants in each treatment category to the analyses. Foliar samples were dried $\left(65^{\circ} \mathrm{C}, 24 \mathrm{~h}\right)$ and milled to a fine powder. Powdered samples weighing $1.8 \mathrm{mg}$ each were sealed in foil capsules. Measurements of $\mathrm{N} \%$ and stable isotope ratios of $\mathrm{N}$ were determined using an elemental analyzer (Flash EA1112, Carlo Erba) connected to a Finnigan Deltaplus Advantage (Thermo Electron Corp., Waltham, USA) continuous flow isotope ratio mass spectrometer (CFIRMS). Natural abundances of ${ }^{15} \mathrm{~N}$ are expressed in per mil (\%o) deviation from international standards: $\delta^{15} \mathrm{~N}=$ ( $\mathrm{R}$ sample / $\mathrm{R}$ standard -1$) \times 1000$, where $\mathrm{R}$ is the ratio of ${ }^{15} \mathrm{~N} /{ }^{14} \mathrm{~N}$. Atmospheric nitrogen was used as the international standard.

\section{Statistical analyses}

We used three-way ANOVA to analyze dry biomass, root:shoot ratio, $\mathrm{N} \%$ and $\mathrm{N}$ content in the adult plants and seedlings separately. In the ANOVA models competition (absent, present), AMF (absent, present) and $\mathrm{N}$ source (ammonium, glycine) were treated as fixed factors. In the $\delta^{15} \mathrm{~N}$ analysis, due to the different source $\delta^{15} \mathrm{~N}$ values of the two nitrogen treatments, we analyzed ammonium and glycine grown plants separately and used two-way ANOVA. Fixed factors in the ANOVA model were competition (absent, present), AMF (absent, present). Mycorrhizal benefit for biomass and $\mathrm{N}$ content were calculated by dividing mycorrhizal values by the average non-mycorrhizal value in the respective treatment. Variables of mycorrhizal benefit for the AM adults and seedlings were analyzed with three-way ANOVA using life stage (adult, seedling), competition (absent, present) and $\mathrm{N}$ source (ammonium, glycine) as fixed factors in the models. Two-way ANOVA was used to analyze AMF colonization (hyphae, arbuscules and vesicles) and treating competition (presence, absence) and $\mathrm{N}$ source (ammonium, glycine) as fixed factors. 
Seedling dry biomass and $\mathrm{N}$ content and mycorrhizal benefit values were $\log 10$ transformed to meet the assumptions of ANOVA. In the experiment, three seedlings were growing with an adult, and the mean value of the three seedlings was used in the analyses. At the end of the experiment, all the seedlings and $92.5 \%$ of the adults were alive. Dead plants were not included in the analyses. Homoscedasticity was assessed by using Levene's test and the normality of data by checking the normality of residuals. Tukey's multiple comparison test was used to assess the significance between more than two means in models with significant interactions between factors. All statistical analyses were implemented with IBM SPSS Statistics version 22 (SPSS Inc.) and the R statistical environment (R Development Core Team, 2014) using the CAR package for GLMs.

\section{Results}

Adult plant biomass was not straight forward affected by competition or AMF (Tables 1 and 2). Nitrogen source interacted with the effect of AMF (Table 1; Table 2: $\mathrm{N}$ source $\mathrm{x}$ AMF interaction). Nitrogen source had no effect on growth when the adult plants were mycorrhizal, but NM adult plants grew more when they received glycine than when given ammonium (NM adults: $\mathrm{F}_{3,36}=11.145, \mathrm{p}=0.002$, mycorrhizal adults: $\mathrm{F}_{3,30}=2.593, \mathrm{p}=0.118$ ).

Seedling biomass was affected by competition but not by AMF (Tables 1 and 2). The negative effect of competition interacted with the effect of $\mathrm{N}$ source (Table 2). In the absence of competition, the applied $\mathrm{N}$ source was important to the seedling growth (competition present: $\mathrm{F}_{3,36}=1.345, \mathrm{p}=0.254$, competition absent: $\left.F_{3,36}=19.402, p<0.001\right)$. Seedlings without the adult grew best with ammonium (Table 1).

The $\mathrm{N}$ content of the adult plants was highest when NM and grown with glycine (Tables 1 and 2). Adult shoot $\mathrm{N}$ content (mean $3.31 \pm 0.18$ ) was over 4 times higher than that of the seedlings (mean $0.74 \pm 0.12$ ) (one-way ANOVA $\mathrm{F}_{1,77}=131.071, \mathrm{p}<0.001$ ). Adult shoot $\mathrm{N} \%$ remained constant in all treatments and plant $\mathrm{N}$ content was determined mainly by plant size (Table 1 and 2). In contrast, seedling N\% varied between treatments (Table 1 and 2).
Competition and glycine treatment lowered seedling $\mathrm{N}$ content, but AMF had no effect (Tables 1 and 2).

Root:shoot ratio of the adult plants was not affected by the $\mathrm{N}$ source (Table 1). AMF increased the ratio in adults significantly, but only in absence of competition (Tables 1 and 2). In contrast, seedling root:shoot ratio was increased by competition, but not by AMF or $\mathrm{N}$ source (Tables 1 and 2).

Similar to the root:shoot ratio, competition did not affect adult plant AMF colonization in a straightforward way (Table 3). Glycine increased the frequency of arbuscules in adult plants, but only in absence of competition (Table 3, competition present: $\mathrm{F}_{1,8}=0.700, \mathrm{p}=0.427$, competition absent: $\left.\mathrm{F}_{1,8}=16.275, \mathrm{p}=0.004\right)$. In contrast, the frequency of intraradical hyphae was higher in competing seedlings when provided with glycine than with ammonium (Table 3).

Competition and AMF raised the $\delta^{15} \mathrm{~N}$ value in the adults when provided with ammonium (Fig. 1a). When the plants were provided with glycine, singly grown mycorrhizal plants had higher $\delta^{15} \mathrm{~N}$ value than respective NM plants. Competition reversed this pattern in adults, but not in seedlings (Fig. 1b). Glycine provided adult plants had higher foliar $\delta^{15} \mathrm{~N}$ values when compared with ammonium provided plants. This result reflected the isotopic signal of the $\mathrm{N}$ sources which was negative in case of ammonium $(-3.203)$ and positive in glycine (+1.205). Competition lowered seedling foliar $\delta^{15} \mathrm{~N}$ in both nitrogen treatments (Fig. 1). AMF presence increased the $\delta^{15} \mathrm{~N}$ value, but in glycine provided seedlings only (Fig. 1). Therefore, similar to adults, there was no overall clear trend of AMF raising or lowering the foliar $\delta^{15} \mathrm{~N}$ signal in seedlings. In contrast to adult plants, $\mathrm{N}$ source did not have significant effects on seedling $\delta^{15} \mathrm{~N}$.

Plant life stage, competition and $\mathrm{N}$ source interacted statistically significantly in terms of mycorrhizal biomass benefit (Fig. 2, Supplementary Table 1). Multiple comparison indicates that mycorrhizal benefit was significantly lower in glycine provided seedlings when competing in comparison to all other treatments (Fig. 2, Supplementary Table 1). When analysing the mycorrhizal biomass benefit in adults and seedlings separately, competition reduced mycorrhizal growth benefit in adults supplied with ammonium (competition present: $\mathrm{F}_{1,18}=2.999, \mathrm{p}=0.100$, competition absent: $\left.\mathrm{F}_{1,12}=12.810, \mathrm{p}=0.004\right)$. 

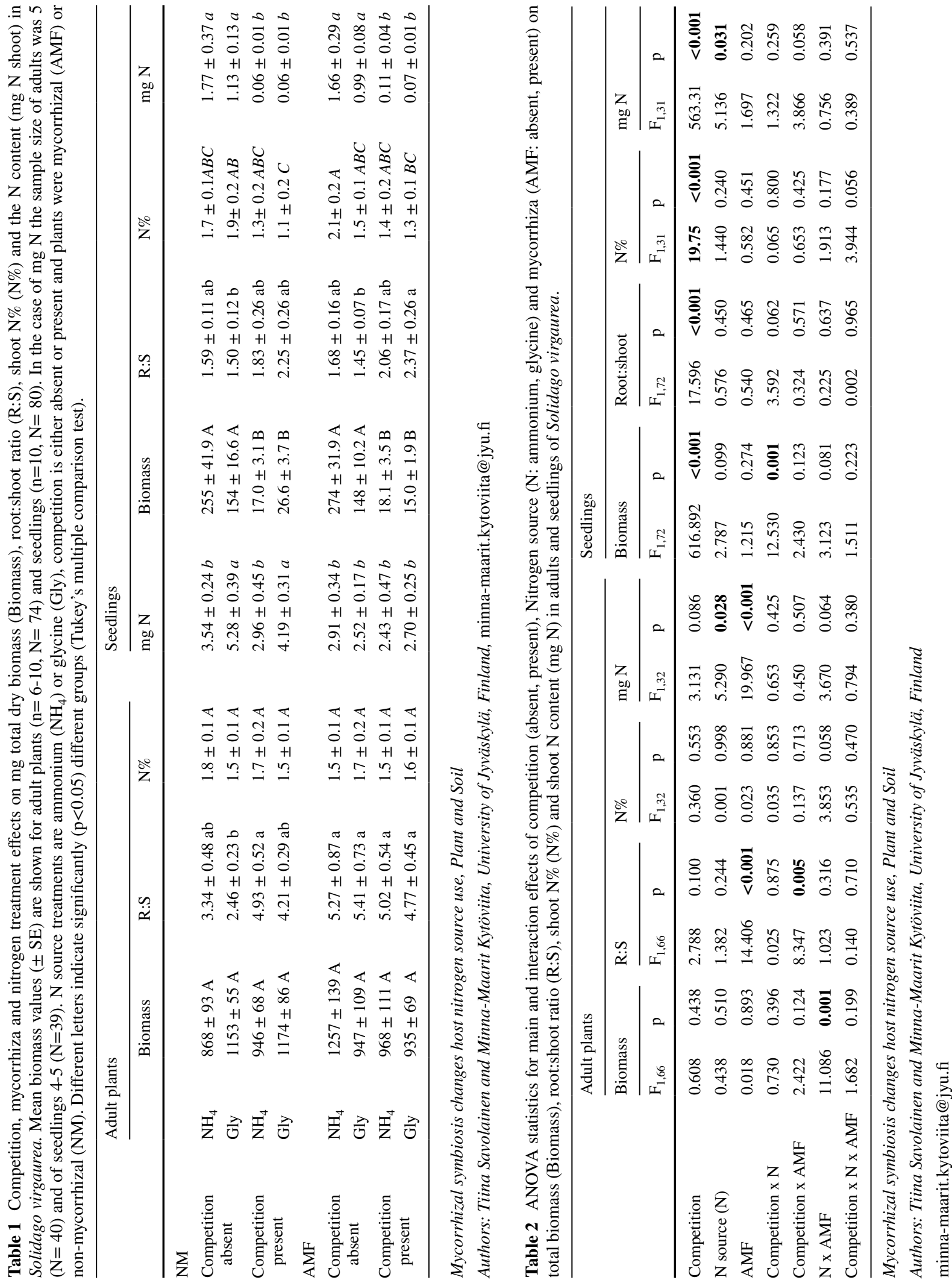
Table 3 Mean values ( \pm SE, $n=5$ ) of the frequency $(\%)$ of mycorrhizal hyphae, vesicles and arbuscules in adults and seedlings of Solidago virgaurea. Values are reported when plants were grown without competition (competition absent) or when competing (competition present) and when grown with the $\mathrm{N}$ source ammonium $\left(\mathrm{NH}_{4}\right)$ or glycine (Gly). Different letters indicate significantly $(\mathrm{p}<0.05)$ different groups (Tukey's multiple comparison test). Below the mean values, respective p-values of the factorial ANOVA test are given (factors: competition, $\mathrm{N}$ source).

\begin{tabular}{|c|c|c|c|c|c|c|c|}
\hline & \multicolumn{4}{|c|}{ Adults } & \multicolumn{3}{|l|}{ Seedlings } \\
\hline & & Hyphae-\% & Vesicles-\% & Arbuscules- $\%$ & Hyphae-\% & Vesicles-\% & Arbuscules- $\%$ \\
\hline \multirow[t]{2}{*}{ Competition absent } & $\mathrm{NH}_{4}$ & $49 \pm 10$ & $7 \pm 2$ & $18 \pm 5 \mathrm{~A}$ & $80 \pm 2 \mathrm{AB}$ & $5 \pm 3$ & $53 \pm 3$ \\
\hline & Gly & $77 \pm 4$ & $5 \pm 2$ & $47 \pm 5 B$ & $87 \pm 2 \mathrm{~B}$ & $5 \pm 1$ & $58 \pm 5$ \\
\hline \multirow[t]{3}{*}{ Competition present } & $\mathrm{NH}_{4}$ & $50 \pm 9$ & $8 \pm 3$ & $27 \pm 6 \mathrm{AB}$ & $66 \pm 7 \mathrm{~A}$ & $4 \pm 2$ & $38 \pm 8$ \\
\hline & Gly & $\begin{array}{l}51 \pm 3 \\
\text { p-values }\end{array}$ & $6 \pm 1$ & $21 \pm 5 \mathrm{~A}$ & $88 \pm 3 \mathrm{~B}$ & $\begin{array}{l}5 \pm 1 \\
\text { p-values }\end{array}$ & $55 \pm 9$ \\
\hline & & Hyphae & Vesicles & Arbuscules & Hyphae & Vesicles & Arbuscules \\
\hline Competition & & 0.102 & 0.631 & 0.138 & 0.118 & 0.793 & 0.183 \\
\hline $\mathrm{N}$ source & & 0.061 & 0.514 & 0.044 & 0.002 & 0.637 & 0.116 \\
\hline Competition $\mathrm{x} \mathrm{N}$ source & & 0.083 & 0.965 & 0.004 & 0.075 & 0.958 & 0.360 \\
\hline
\end{tabular}

Mycorrhizal symbiosis changes host nitrogen source use, Plant and Soil

Authors: Tiina Savolainen and Minna-Maarit Kytöviita, University of Jyväskylä, Finland

minna-maarit.kytoviita@jyu.fi

Plant life stage, competition and $\mathrm{N}$ source had a significant main effect on mycorrhizal $\mathrm{N}$ benefit (Fig. 2, Supplementary Table 1). Average mycorrhizal $\mathrm{N}$ benefit was higher in seedlings $(1.17 \pm 0.16)$ than in adults $(0.69 \pm 0.06)$, higher when supplied with ammonium $(1.10 \pm 0.16)$ than with glycine $(0.79$ $\pm 0.07)$, and higher in competing plants $(1.10 \pm 0.16)$ than in those grown solitarily $(0.78 \pm 0.06)$ (Fig. 2 , Supplementary Table 1).

\section{Discussion}

Niche partitioning of resources due to interspecific differences in structural and physiological traits have been considered to explain the coexistence of many species in plant communities (Levine and HilleRisLambers 2009; Silvertown 2004). Ecologists accept that plants capture $\mathrm{N}$ in many chemical forms including amino acids (Lipson and Näsholm 2001; Schimel and Bennett 2004). However, less is known about plasticity in $\mathrm{N}$ use within species although it is a critical parameter in defining the organism's competitive ability and, in the end, the realized niche (Miller et al. 2007). Here we show plasticity in $\mathrm{N}$ use in response to intraspecific competition and in response to mycorrhizal symbiosis, two prevailing ecological factors in plant life.
Despite differences in $\mathrm{N}$ source use when nonmycorrhizal, both adults and seedlings of mycorrhizal Solidago virgaurea performed equally when supplied with $\mathrm{NH}_{4}$ as the $\mathrm{N}$ source. The $\mathrm{N}$ use of a mycorrhizal plant may be affected by the $\mathrm{N}$ preference of the AMF, however, it is difficult to disentangle the inherent nutrient preferences of the obligatorily symbiotic fungus. In experiments with isolated hyphae many AMF isolates have preferred ammonium over amino acids (Hawkins et al. 2000). Although AMF have been shown to take up also organic $\mathrm{N}$, mainly in the form of amino acids (Whiteside et al. 2012), and transfer $\mathrm{N}$ to their host plants, many plant species have been shown to perform better when given ammonium than amino acids when mycorrhizal (Ashton et al. 2008; Harrison et al. 2007). AMF are capable of direct glycine uptake (Hawkins et al. 2000; Koegel et al. 2015), but AM plant $\mathrm{N}$ acquisition from glycine is less than from other soil amino acids in some cases (Hodge 2001; Whiteside et al. 2012, but see Koegel et al. 2015).

Stable $\mathrm{N}$ isotopes are used to investigate the source and movement of $\mathrm{N}$ in studies extending from individual plants to landscapes. Plants may discriminate ${ }^{15} \mathrm{~N}$ as a result of partial utilization of the available N source (Hobbie and Colpaert 2003; McKee et al. 2002). Plant $\delta^{15} \mathrm{~N}$ values may be affected further by different $\mathrm{N}$ acquisition strategies (Hobbie et al. 


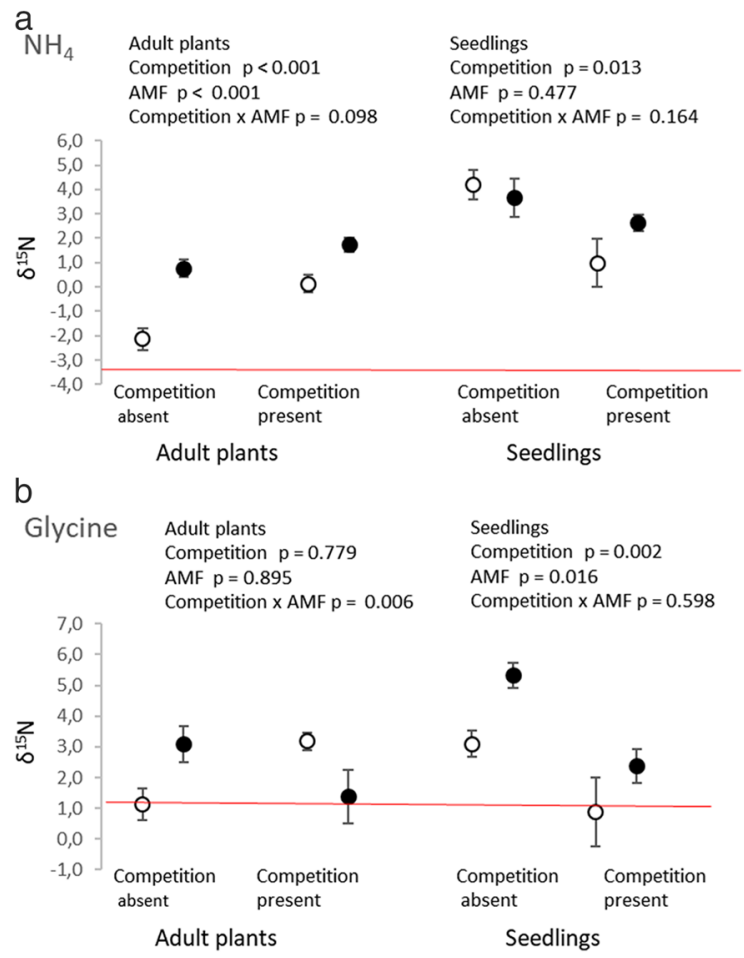

Fig. 1 Mean $\delta^{15} \mathrm{~N}$ values in A) ammonium or B) glycine grown Solidago virgaurea adults $(n=5)$ and seedlings $(n=4-5)$ when competition and mycorrhiza are either absent or present. Open symbols refer to non-mycorrhizal plants, closed symbols to mycorrhizal plants. The horizontal red lines illustrate the $\mathrm{N}$ source $\delta^{15} \mathrm{~N}$ : -3.203 for ammonium and +1.205 for glycine
2000) that include the use of inorganic or organic $\mathrm{N}$ sources or the role of mycorrhizal symbiosis (Handley and Scrimgeour 1997; Michelsen et al. 1996). In our study, competition did not interact with $\mathrm{N}$ source in terms of mycorrhizal $\mathrm{N}$ benefit, but plant $\delta^{15} \mathrm{~N}$ responded differently to competition and AMF. Despite no change in the net $\mathrm{N}$ acquisition by the plants, $\delta^{15} \mathrm{~N}$ data shows that competition and AMF affect plant $\mathrm{N}$ relations. Published results on plant $\delta^{15} \mathrm{~N}$ modification by AMF inoculation vary and are challenging to compare with the present study. For instance, a decrease (Azcon et al. 1998; Handley et al. 1993) and increase (Azcon et al. 1998; Fonseca et al. 2001) in shoot $\delta^{15} \mathrm{~N}$ values following inoculation are reported. In contrast to our results, it has been proposed that the mycorrhizal transfer should generally decrease foliar $\delta^{15} \mathrm{~N}$ signatures because of the effects of isotopic fractionation where mycorrhizal fungi discriminate against the heavier ${ }^{15} \mathrm{~N}$ isotope leaving the plant depleted in ${ }^{15} \mathrm{~N}$ (i.e. with a more negative $\delta^{15} \mathrm{~N}$ value) (Handley et al. 1999; Hobbie et al. 1999, 2000). Nitrogen availability and demand affect ${ }^{15} \mathrm{~N}$ discrimination in plants (Evans 2001). Positive and negative ${ }^{15} \mathrm{~N}$ fractionation as a result of partial use of the plant available $\mathrm{N}$ may have occurred if other nutrients were even more limiting than $\mathrm{N}$ to plant growth (McKee et al. 2002; Wanek and Zotz 2011). We consider nutrient limitation other than nitrogen unlikely in our system. The nutrients were supplied in balanced nutrient solution whilst the $\mathrm{N} \%$ in

\section{Mycorrhizal $\mathrm{N}$ benefit}

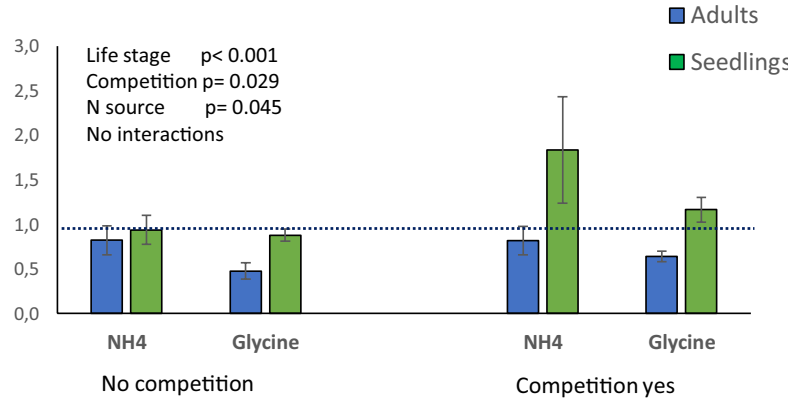

three-way ANOVA results are shown, full ANOVA table is shown in Supplementary Table 1. Different letters indicate significantly $(\mathrm{p}<0.05)$ different groups in case of significant interactions between factors (Tukey's multiple comparison test). Horizontal dotted lines illustrate when there is no net cost nor benefit of mycorrhiza. 
the experimental plants was 1.2-1.8. Altogether, our results do not give full support to the idea that variability in foliar $\delta^{15} \mathrm{~N}$ values corresponds directly to differences in source $\delta^{15} \mathrm{~N}$ (Falkengren-Grerup et al. 2004; Miller and Bowman 2002). Instead, our results agree with the notion that there are other obscuring factors present, such as plant internal transformations or other physiological mechanisms in $\mathrm{N}$ assimilation (Evans 2001; Handley et al. 1998).

Glycine increased colonization rates in absence of competition in adult plants and in presence of competition in seedlings. To our knowledge, there is only one report of effects of $\mathrm{N}$ source on mycorrhiza colonization frequency in plant roots previously. Onions had higher arbuscular mycorrhizal colonization level when grown with $\mathrm{NO}_{3}$ as the predominant $\mathrm{N}$ source compared with $\mathrm{NH}_{4}$ (Perner et al. 2008). Different $\mathrm{N}$ sources have been shown to affect metabolic pathways in arbuscular mycorrhizal hyphae (Breuninger et al. 2004). Therefore, changes in fungal physiology due to different $\mathrm{N}$ source uptake may have affected the colonization rate. Although colonization intensity increased in glycine-supplied competing seedlings and in adults in absence of competition, plant mycorrhizal benefit was lower when provided with glycine than with $\mathrm{NH}_{4}$, suggesting that the fungus retained proportionally more resources from glycine to its own benefit. The carbon moiety in the amino acid may have supplemented the fungal carbon needs (Fellbaum et al. 2012) and in that way facilitated higher colonization of roots. Amino acids are known to be taken up by the fungus during pre-symbiotic growth, i.e. before the symbiosis with the host plant is established (Gachomo et al. 2009). Furthermore, pre-symbiotic AM hyphae have been shown to take up and utilize external carbon sources to supplement their $\mathrm{C}$ needs (Bücking et al. 2008). For example, AM may use myristate, a common root exudate, as a $\mathrm{C}$ source when grown asymbiotically (Sugiura et al. 2020). Although AM fungi are incapable of completing their life cycle without host plants (Smith and Read, 2008), our results suggest that soil organic nitrogen sources may allow fungus to trade less resources with the host. This scenario needs to be evaluated by tracing the flow of $\mathrm{N}$ and $\mathrm{C}$ between the symbionts when grown with organic and inorganic $\mathrm{N}$.

We did not determine the extent to which the amino acids, ammonium or nitrate might have been transformed before or after uptake. Therefore, our results infer the importance and effect of these $\mathrm{N}$ sources including their possible transformations. In our experiment, AMF did not improve plant growth and we recognize that this result may be specific to the present growth conditions. Previously, it has been shown that under low nutrient availability, AMF may not benefit plants (Püschel et al. 2016). In our parallel study using isotopic labeling and mycorrhizal compartments, the Glomus hoi isolate we used in the current experiment transferred inorganic $\mathrm{N}$ to host plants and improved S. virgaurea growth (Kytöviita and Savolainen, manuscript). The length of the present experiment was 15 weeks and it may be that $G$. hoi requires longer time to be able to pay back the $\mathrm{C}$ costs and provide growth benefits to plants as has been suggested in other mycorrhizal systems (Johnson et al. 1997; Veresoglou et al. 2012). Pre-growth period is necessary to rear plants to adulthood, however, the pre-growth conditions may affect adult plant responses to the treatments.

In line with the few previous studies with Arctic plants where competition reduced mycorrhizal growth benefit in intraspecific seedlings (Kytöviita et al. 2003; Pietikäinen and Kytöviita 2007), intraspecific competition reduced mycorrhizal growth benefit in the glycine grown seedlings in the present work. However, competition increased mycorrhizal benefit in terms of shoot total $\mathrm{N}$ in seedlings suggesting that seedlings are a sink for mycorrhiza-mediated nitrogen. Altogether plants competed strongly both when NM and when mycorrhizal. The suppressive effect by the adult co-specific $S$. virgaurea neighbors and persistence of seedlings is also evident in our long-term experimental field sites (Savolainen and Kytöviita 2017).

The present symbiosis -mediated reduction in organic $\mathrm{N}$ use has potential repercussions on ecosystem functions such as productivity and nutrient losses from the systems through leaching. It is evident that further studies are needed to gain a more general understanding to which extent plant competition for resources affects functional differences among and within species in communities of varying plant diversity in the Arctic. Our study, however, clearly shows that analyses to explain species coexistence and community assembly require the incorporation of intraspecific competition and mycorrhizal fungi. Further knowledge on the role of nitrogen on AMF ecology is needed to fully evaluate the role of organic nitrogen on cold climate 
vegetation and $\mathrm{N}$ deposition effects on northern ecosystems. Research on mycorrhizal symbiosis is so-far conducted mainly with young plants. Further research on how ontogeny may affect symbiotic relationships is necessary to elucidate the ecological importance of mycorrhiza-mediated nutrient acquisition form different $\mathrm{N}$ sources.

Acknowledgements We wish to thank Dr Tuula Sinisalo (University of Jyväskylä) for the help with the SIA analysis and Dr Heli Juottonen (University of Jyväskylä) for commenting the manuscript.

Availability of data and material The data generated during this work is deposited in the Jyväskylä University open Digital Repository JYKDOX.

Code availability not applicable

Authors' contributions MMK designed the study, TS conducted the greenhouse experiment and data acquisition, TS and MMK conducted the statistical analyses and TS and MMK wrote the paper.

Funding Open Access funding provided by University of Jyväskylä (JYU). This work was supported by Central Finland Regional Fund (TS), University of Jyväskylä (TS, MMK), the Finnish Cultural Foundation (TS) and Academy of Finland (MMK, grant number 127 657).

\section{Declarations}

Conflicts of interest/Competing interests The authors declare no competing interests or conflict of interest.

Ethics approval This research did not involve human participants or animals

\section{Consent to participate Not applicable}

Consent for publication We, the authors of this manuscript will give consent to the publisher of the journal Plant and Soil to publish the manuscript 'Mycorrhizal symbiosis changes host nitrogen source use' should the manuscript be deemed publishable after appropriate review process.

Open Access This article is licensed under a Creative Commons Attribution 4.0 International License, which permits use, sharing, adaptation, distribution and reproduction in any medium or format, as long as you give appropriate credit to the original author(s) and the source, provide a link to the Creative Commons licence, and indicate if changes were made. The images or other third party material in this article are included in the article's Creative Commons licence, unless indicated otherwise in a credit line to the material. If material is not included in the article's Creative Commons licence and your intended use is not permitted by statutory regulation or exceeds the permitted use, you will need to obtain permission directly from the copyright holder. To view a copy of this licence, visit http://creativecommons.org/licenses/by/4.0/.

\section{References}

Ashton IW, Miller AE, Bowman WD, Suding KN (2008) Nitrogen preferences and plant-soil feedbacks as influenced by neighbors in the alpine tundra. Oecologia 156:625-636

Azcon-G-Aguilar R, Handley LL, Scrimgeour CM (1998) The delta $15 \mathrm{~N}$ of lettuce and barley are affected by AM status and external concentration of N. New Phytol 138:19-26

Breuninger M, Trujillo CG, Serrano E, Fischer R, Requena N (2004) Different nitrogen sources modulate activity but not expression of glutamine synthetase in arbuscular mycorrhizal fungi. Fungal Genet Biol 41:542-552

Britto DT, Kronzucker HJ (2013) Ecological significance and complexity of $\mathrm{N}$-source preference in plants. Ann Bot 112:957-963

Brundrett MC (2002) Coevolution of roots and mycorrhizas of land plants. New Phytol 154:275-304

Bücking H, Abubaker J, Govindarajulu M, Tala M, Pfeffer PE, Nagahashi G, Lammers P, Shachar-Hill Y (2008) Root exudates stimulate the uptake and metabolism of organic carbon in germinating spores of Glomus intraradices. New Phytol 180:684-695

Chapin FS, Moilanen L, Kielland K (1993) Preferential use of organic nitrogen for growth by a non-mycorrhizal arctic sedge. Nature 361:150-153

Dawson TE, Mambelli S, Plamboeck AH, Templer PH, Tu KP (2002) Stable Isotopes in Plant Ecology. Annu Rev Ecol Syst 33:507-559

Evans R (2001) Physiological mechanisms influencing plant nitrogen isotope composition. Trends Plant Sci 6:121-126

Falkengren-Grerup U, Michelsen A, Olsson M, Quarmby C, Sleep D (2004) Plant nitrate use in deciduous woodland: the relationship between leaf $\mathrm{N},{ }^{15} \mathrm{~N}$ natural abundance of forbs and soil $\mathrm{N}$ mineralisation. Soil Biol Biochem 36:1885-1891

Fellbaum CR, Gachomo EW, Beesetty Y, Choudhari S, Strahan GD, Pfeffer PE, Kiers ET, Bücking H (2012) Carbon availability triggers fungal nitrogen uptake and transport in arbuscular mycorrhizal symbiosis. PNAS 109:2666-2671

Fonseca HM, Berbara RL, Daft MJ (2001) Shoot $\delta^{15} \mathrm{~N}$ and $\delta^{13} \mathrm{C}$ values of non-host Brassica rapa change when exposed to Glomus etunicatum inoculum and three levels of phosphorus and nitrogen. Mycorrhiza 11:151-158

Gachomo E, Allen JW, Pfeffer PE, Govindarajulu M, Douds DD, Jin H, Nagahashi G, Lammers PJ, Shachar-Hill Y, Bücking H (2009) Germinating spores of Glomus intraradices can use internal and exogenous nitrogen sources for de novo biosynthesis of amino acids. New Phytol 184:399-411

Gardes M, Dahlberg A (1996) Mycorrhizal diversity in arctic and alpine tundra: an open question. New Phytol 133:147-157

Govindarajulu M, Pfeffer PE, Jin H, Abubaker J, Douds DD, Allen JW, Bücking H, Lammers PJ, Shachar-Hill Y 
(2005) Nitrogen transfer in the arbuscular mycorrhizal symbiosis. Nature 435:819-823

Grace JB, Tilman D (2003) Perspectives on plant competition. Blackburn Press, Caldwell

Handley LL, Azcón R, Lozano JMR, Scrimgeour CM (1999) Plant $\delta^{15} \mathrm{~N}$ associated with arbuscular mycorrhization, drought and nitrogen deficiency. Rapid Commun Mass Spectrom 13:1320-1324

Handley LL, Daft MJ, Wilson J, Scrimgeour CM, Ingleby K, Sattar MA (1993) Effects of the ecto- and VA-mycorrhizal fungi Hydnagium carneum and Glomus clarum on the delta ${ }^{15} \mathrm{~N}$ and delta ${ }^{13} \mathrm{C}$ values of Eucalyptus globulus and Ricinus communis. Plant Cell Environ 16:375-382

Handley LL, Scrimgeour C (1997) Terrestrial Plant Ecology and ${ }^{15} \mathrm{~N}$ Natural Abundance: The Present Limits to Interpretation for Uncultivated Systems with Original Data from a Scottish Old Field. Adv Ecol Res 27:133-212

Handley LL, Scrimgeour CM, Raven JA (1998) ${ }^{15} \mathrm{~N}$ natural abundance levels in terrestrial vascular plants: a précis. In: Griffiths H (ed) Stable isotopes. BIOS, Oxford, pp 89-98

Harrison KA, Bol R, Bardgett RD (2007) Preferences for different nitrogen forms by coexisting plant species and soil microbes. Ecology 88:989-999

Hawkins HJ, Johansen A, George E (2000) Uptake and transport of organic and inorganic nitrogen by arbuscular mycorrhizal fungi. Plant Soil 226:275

Hobbie EA, Colpaert JV (2003) Nitrogen availability and colonization by mycorrhizal fungi correlate with nitrogen isotope patterns in plants. New Phytol 157:115-126

Hobbie EA, Högberg P (2012) Nitrogen isotopes link mycorrhizal fungi and plants to nitrogen dynamics. New Phytol 196:367-382

Hobbie EA, Macko SA, Shugart HH (1999) Interpretation of nitrogen isotope signatures using the NIFTE model. Oecologia 120:405-415

Hobbie EA, Macko SA, Williams M (2000) Correlations between foliar $\delta^{15} \mathrm{~N}$ and nitrogen concentrations may indicate plant-mycorrhizal interactions. Oecologia $122: 273-283$

Hodge A (2001) Arbuscular mycorrhizal fungi influence decomposition of, but not plant nutrient capture from, glycine patches in soil. New Phytol 151:725-734

Hodge A, Storer K (2014) Arbuscular mycorrhiza and nitrogen: implications for individual plants through to ecosystems. Plant Soil 386:1-19

Högberg P (1997) Tansley Review No. 95. ${ }^{15} \mathrm{~N}$ natural abundance in soil-plant systems. New Phytol 137:179-203

Hultén E, Fries M (1986) Atlas of North European vascular plants. Koeltz scientific Books

Ingestad T (1960) Studies on the Nutrition of Forest Tree Seedlings. III Mineral Nutrition of Pine. Physiol Plantarum 13:513-533

Jalas J (1980) Solidago virgaurea L. - Kultapiisku. Suuri kasvikirja III Suomen luonto (ed. J. Jalas), pp. 685-688. Otava, Helsinki.

Johnson NC, Graham JH, Smith FA (1997) Functioning of mycorrhizal associations along the mutualism-parasitism continuum. New Phytol 135:575-585

Keddy PA (2001) Competition. Kluwer academic publ, Dordrecht
Kielland K (1994) Amino acid absorption by Arctic plants: implications for plant nutrition and nitrogen cycling. Ecology $75: 2373$

Kielland K (1995) Landscape patterns of free amino acids in arctic tundra soils. Biogeochemistry 31:85-98

Koegel S, Brulé D, Wiemken A, Boller T, Courty P-E (2015) The effect of different nitrogen sources on the symbiotic interaction between Sorghum bicolor and Glomus intraradices: Expression of plant and fungal genes involved in nitrogen assimilation. Soil Biol Biochem 86:159-163

Kytöviita M-M, Pietikäinen A, Fritze H (2011) Soil microbial and plant responses to the absence of plant cover and monoculturing in low arctic meadows. Appl Soil Ecol 48:142-151

Kytöviita M-M, Vestberg M, Tuomi J (2003) A Test Of Mutual Aid In Common Mycorrhizal Networks: Established Vegetation Negates Benefit In Seedlings. Ecology 84:898-906

Levine JM, HilleRisLambers J (2009) The importance of niches for the maintenance of species diversity. Nature 461:254-257

Lipson DA, Raab TK, Schmidt SK, Monson RK (1999) Variation in competitive abilities of plants and microbes for specific amino acids. Biol Fertil Soils 29:257-261

Lipson D, Näsholm T (2001) The unexpected versatility of plants: organic nitrogen use and availability in terrestrial ecosystems. Oecologia 128:305-316

McGonigle TP, Miller MH, Evans DG, Fairchild GL, Swan JA (1990) A new method which gives an objective measure of colonization of roots by vesicular-arbuscular mycorrhizal fungi. New Phytol 115:495-501

McKane RB, Johnson LC, Shaver GR, Nadelhoffer KJ, Rastetter EB, Fry B, Giblin AE, Kielland K, Kwiatkowski BL, Laundre JA, Murray G (2002) Resource-based niches provide a basis for plant species diversity and dominance in arctic tundra. Nature 415:68-71

McKee KL, Feller IC, Popp M, Wanek W (2002) Mangrove Isotopic $\left(\delta^{15} \mathrm{~N}\right.$ and $\left.\delta^{13} \mathrm{C}\right)$ Fractionation across a Nitrogen vs. Phosphorus Limitation Gradient. Ecology 83:1065

Michelsen A, Schmidt IK, Jonasson S, Quarmby C, Sleep D (1996) Leaf ${ }^{15} \mathrm{~N}$ abundance of subarctic plants provides field evidence that ericoid, ectomycorrhizal and non-and arbuscular mycorrhizal species access different sources of soil nitrogen. Oecologia 105:53-63

Mickan BS, Hart M, Solaiman ZM, Renton M, Kadambot H, Siddique M, Jenkins SM, Abbott LK (2021) Arbuscular mycorrhizal fungus-mediated interspecific nutritional competition of a pasture legume and grass under drought stress. Rhizosphere 18:100349

Miller AE, Bowman WD (2002) Variation in nitrogen-15 natural abundance and nitrogen uptake traits among co-occurring alpine species: do species partition by nitrogen form? Oecologia 130:609-616

Miller AE, Bowman WD, Suding KN (2007) Plant Uptake Of Inorganic And Organic Nitrogen: Neighbor Identity Matters. Ecology 88:1832-1840

Moora M, Zobel M (1998) Can arbuscular mycorrhiza change the effect of root competition between conspecific plants of different ages? Can J Bot 76:613-619

Näsholm T, Ekblad A, Nordin A, Giesler R, Högberg M, Högberg P (1998) Boreal Forest Plants Take up Organic Nitrogen. Nature 392:914-916 
Nordin A, Schmidt IK, Shaver GR (2004) Nitrogen uptake by Arctic soil microbes and plants in relation to soil nitrogen supply. Ecology 85:955-962

Olofsson J, Kitti H, Rautiainen P, Stark S, Oksanen L (2001) Effects of summer grazing by reindeer on composition of vegetation, productivity and nitrogen cycling. Ecography 24:13-24

Perner H, Rohn S, Driemel G, Batt N, Schwarz D, Kroh LW, George E (2008) Effect of Nitrogen Species Supply and Mycorrhizal Colonization on Organosulfur and Phenolic Compounds in Onions. J Agr Food Chem 56:3538-3545

Pietikäinen A, Kytöviita M-M (2007) Defoliation changes mycorrhizal benefit and competitive interactions between seedlings and adult plants. J Ecol 95:639-647

Pietikäinen A, Kytöviita M-M, Vuoti U (2005) Mycorrhiza and seedling establishment in a subarctic meadow: Effects of fertilization and defoliation. J Veg Sci 16:175

Püschel D, Janoušková M, Hujslová M, Slavíková R, Gryndlerová H, Jansa J (2016) Plantfungus competition for nitrogen erases mycorrhizal growth benefits of Andropogon gerardii under limited nitrogen supply. Ecol Evol 6:4332-4346

R Development Core Team (2014) R: a language and environment for statistical computing. R Foundation for Statistical Computing, Vienna, Austria

Redecker D, Kodner R, Graham LE (2000) Glomalean Fungi from the Ordovician. Science 289:1920-1921

Robinson D (2001) $\delta 15 \mathrm{~N}$ as an integrator of the nitrogen cycle. Trends Ecol Evol 16:153-162

Savolainen T, Kytöviita M-M (2017) Competition for resources is ameliorated by niche differentiation between Solidago virgaurea life-history stages in the Arctic. J Plant Ecol 10:907-917

Schimel JP, Bennett J (2004) Nitrogen Mineralization: Challenges Of A Changing Paradigm. Ecology 85:591-602

Silvertown J (2004) Plant coexistence and the niche. Trends Ecol Evol 19:605-611

Skogland T (1980) Comparative Summer Feeding Strategies of Arctic and Alpine Rangifer. J Animal Ecol 49:81-98
Smith SE, Read DJ (2008) Mycorrhizal symbiosis. Elsevier, Academic Press, Amsterdam.

Stark S, Kytöviita M-M (2006) Simulated grazer effects on microbial respiration in a subarctic meadow: Implications for nutrient competition between plants and soil microorganisms. Appl Soil Ecol 31:20-31

Stark S (2007) Nutrient cycling in the tundra. In: Marschner P, Rengel Z (eds) Nutrient Cycling in Terrestrial Ecosystems, Soil Biology, vol 10. Springer, Berlin, pp 309-331

Stark S, Strömmer R, Tuomi J (2002) Reindeer grazing and soil microbial processes in two suboceanic and two subcontinental tundra heaths. Oikos 97:69-78

Stitt M, Müller C, Matt P, Gibon Y, Carillo P, Morcuende R, Scheible WR, Krapp A (2002) Steps towards an integrated view of nitrogen metabolism. J Exp Bot 53:959-970

Van der Heijden MGA (2004) Arbuscular mycorrhizal fungi as support systems for seedling establishment in grassland. Ecol Lett 7:293-303

Van der Heijden MGA, Horton TR (2009) Socialism in soil? The importance of mycorrhizal fungal networks for facilitation in natural ecosystems. J Ecol 97:1139-1150

Veresoglou SD, Menexes G, Rillig MC (2012) Do arbuscular mycorrhizal fungi affect the allometric partition of host plant biomass to shoots and roots? A meta-analysis of studies from 1990 to 2010. Mycorrhiza 22:227-235

Wanek W, Zotz G (2011) Are vascular epiphytes nitrogen or phosphorus limited? A study of plant $15 \mathrm{~N}$ fractionation and foliar N:P stoichiometry with the tank bromeliad Vriesea sanguinolenta. New Phytol 192:462-470

Whiteside MD, Garcia MO, Treseder KK (2012) Amino acid uptake in arbuscular mycorrhizal plants. PLoS ONE 7(10):e47643

Publisher's note Springer Nature remains neutral with regard to jurisdictional claims in published maps and institutional affiliations. 